\title{
ANALISIS PENGARUH KOMPETENSI TERHADAP KINERJA DOSEN PERGURUAN TINGGI MARITIM SWASTA DI KOTA SEMARANG \\ Oleh :
}

Cahya Fajar Budi Hartanto, M.Mar., M.Si.

Akademi Pelayaran Niaga Indonesia Semarang

mobile phone: +6281 390710987 ; email: fajar@akpelni.ac.id

\begin{abstract}
Many previous studies have different result in showing effect of the competence to the work performance. That is aim of this research conducted which is to know how the competence has impact to the performance of lecturers in private maritime higher educations in Semarang.

Research's respondents are 54 lecturers from 3 private maritime higher educations in Semarang known as Akpelni, Stimart-AMNI, and ATP Veteran. According to this research, competence has high score as 4.25 and performance is lower than competence which is 3.97.

Analysis of linier regression $\mathrm{Y}=0.93+0.72 \mathrm{X}$ means that every improvement in competence $(\mathrm{X})$ will also increase the level of performance (Y). Test distribution is normal (sig 0.310), classic assumption is fulfilled ( $\mathrm{sig}$ 0.505). Hypothesis of the research is accepted, there is a significant impact from the competence to the performance of lecturers. The impact is calculated $41 \%$, and the rest is another factors which are not involved in the model.
\end{abstract}

Keywords : Competence, Performance, Lecturers, Private Maritime Higher Education

Disajikan pada Seminar Nasional Kemaritiman di Akademi Maritim Nusantara Cilacap, 26 September 2015 


\section{PENDAHULUAN}

\subsection{Latar Belakang}

Salah satu bagian dari sistem pendidikan nasional yang memiliki peran strategis adalah pendidikan tinggi, yang penyelenggaraannya diatur dalam Undang-Undang Nomor 12 tahun 2012 tentang Pendidikan Tinggi. Menurut Undang-Undang ini, dosen memiliki tugas utama mentransformasikan, mengembangkan, dan menyebarluaskan Ilmu Pengetahuan dan Teknologi melalui Pendidikan, Penelitian, dan Pengabdian kepada Masyarakat.

Pada kenyataannya, kinerja dosen pada perguruan tinggi maritim swasta di kota Semarang belum menampakkan hasil yang memuaskan. Masih sedikitnya karya ilmiah dan pengabdian pada masyarakat menunjukkan rendahnya kinerja dosen, hal ini berakibat kurangnya perolehan sertifikasi dosen. Salah satu penyebab yang disinyalir turut mempengaruhi adalah rendahnya kompetensi akademik dosen. Sebagian dosen mengajar hanya dengan menggunakan sertifikat profesi satu tingkat lebih tinggi dari calon lulusan perguruan tinggi tersebut, sesuai persyaratan dari Kementerian Perhubungan.

Berdasarkan fenomena tersebut, penulis mengembangkan kerangka penelitian yang bertujuan untuk melihat bagaimana kompetensi dan tingkat kinerja dosen di perguruan tinggi maritim swasta di kota Semarang, serta menganalisis adanya pengaruh kompetensi terhadap kinerja dosen. Dengan demikian, sebagai hipotesis awal penelitian ini dirumuskan bahwa ada pengaruh yang signifikan dari kompetensi dosen terhadap kinerja dosen.

\subsection{Landasan Teori}

\subsubsection{Kompetensi Dosen}

Undang-Undang Republik Indonesia Nomor 14 tahun 2005 tentang Guru dan Dosen mendefinisikan kompetensi adalah seperangkat pengetahuan, keterampilan dan perilaku yang harus dimiliki, dihayati, dan dikuasai oleh guru atau dosen dalam melaksanakan tugas keprofesionalan. Penilaian kompetensi juga menjadi salah satu dasar pengangkatan seorang dosen pada jenjang akademik atau jabatan fungsional tertentu.

Peraturan Pemerintah Republik Indonesia Nomor 37 tahun 2009 tentang Dosen menetapkan bahwa seorang dosen dapat menerima sertifikat pendidik setelah melalui uji kompetensi dalam bentuk penilaian portofolio yang menilai pengalaman akademik dan profesional dosen. Dosen yang tidak memenuhi kompetensi yang dipersyaratkan, dapat dikenai sanksi oleh Pemerintah, penyelenggara pendidikan tinggi atau satuan pendidikan tinggi yang diselenggarakan 
masyarakat. Untuk menyesuaikan perubahan substansi keilmuan, teknologi, dan/ atau seni, dosen meningkatkan kompetensi melalui studi lanjut, pelatihan, seminar, dan kegiatan sejenis. Kompetensi dosen terbagi atas : (1) kompetensi pedagogik, yaitu kemampuan mengelola proses pembelajaran dan peserta didik; (2) kompetensi kepribadian, yaitu kepribadian yang mantap, berakhlak mulia, arif, dan berwibawa serta menjadi teladan; (3) kompetensi sosial, yaitu kemampuan berkomunikasi dan berinteraksi secara efektif dan efisien dengan peserta didik, sesama dosen, orang tua/ wali, dan masyarakat sekitar; serta (4) kompetensi profesional, yaitu kemampuan penguasaan materi pelajaran secara luas dan mendalam.

Penelitian ini menggunakan penilaian kompetensi dosen dengan mengacu pada penelitian terdahulu yang dilakukan oleh Rinny (2013), Ade et al. (2013), dan juga diuraikan dalam Naskah Akademik Buku Pedoman Sertifikasi Pendidik untuk Dosen Terintegrasi (2014).

\subsubsection{Kinerja Dosen}

Hamzah B. Uno dan Nina Lamatenggo (2014) menyatakan bahwa terdapat dua tugas yang dijadikan acuan untuk mengukur kinerja tenaga pendidik. Kedua tugas tersebut adalah tugas yang terkait kegiatan proses pembelajaran, dan tugas yang terkait penataan serta perencanaan pembelajaran. Johnson dalam Rinny (2013) menjelaskan bahwa seorang dosen harus memiliki komponen kinerja dalam dirinya. Komponen ini terdiri dari beberapa perilaku, antara lain totalitas dalam keilmuan, keterampilan, pemrosesan dan pengambilan keputusan dalam mencapai tujuan pembelajaran. Dosen dalam pekerjaannya dituntut untuk profesional di bidang ilmunya, berkomitmen pada kualitas dan perbaikan berkelanjutan, mampu memimpin proses pembelajaran, dan senantiasa meningkatkan diri.

Penelitian ini menggunakan standar kinerja dosen berdasarkan teori dari Fortunato dan Waddel (1981) sebagaimana digunakan oleh Rinny Dewi Anggraeni (2013). Standar ini selaras dengan Tri Dharma Perguruan Tinggi yaitu tanggung jawab di bidang pendidikan dan pengajaran, penelitian dan pengembangan riset ilmiah, serta pengabdian pada masyarakat.

\section{METODE PENELITIAN}

\subsection{Metode Pengumpulan Data}

Metode pengumpulan data adalah dengan kuesioner. Seperangkat pertanyaan atau pernyataan tertulis diberikan kepada responden dengan skala Likert, dimana setiap butir instrumen mempunyai gradasi dari sangat positif (skor 5) sampai ke sangat negatif (skor 1). 


\subsection{Populasi dan Sampel}

Populasi menurut Saifuddin (2010) adalah kelompok subjek yang hendak dikenai generalisasi hasil penelitian. Kelompok ini harus memiliki karakter bersama yang membedakannya dari kelompok yang lain. Populasi dalam penelitian ini adalah seluruh dosen pada perguruan tinggi maritim swasta di kota Semarang.

Sampel adalah bagian dari jumlah dan karakteristik yang dimiliki oleh populasi (Sugiyono, 2010). Kesimpulan yang dipelajari dari sampel diberlakukan pada populasi, sehingga harus benar-benar representatif. Penelitian ini menggunakan metode sampel jenuh atau sensus, dimana data diambil dari keseluruhan populasi.

\subsection{Teknik Analisis Data}

\subsubsection{Analisis Deskriptif}

Analisis deskriptif dalam penelitian ini berupa deskripsi responden yang dikelompokkan secara statistik berdasarkan asal institusi, jenis kelamin, usia, tingkat pendidikan (ijazah akademik dan ijazah profesi), serta masa kerja.

\subsubsection{Uji Kualitas Instrumen}

1. Uji Validitas

Uji validitas dilakukan untuk mengetahui apakah butir-butir yang disajikan dalam kuesioner benar-benar mampu mengungkapkan dengan pasti hal yang akan diteliti (Sugiyono, 2010). Untuk itu dilakukan analisis Kaiser-Meyer-Olkin Measure of Sampling Adequacy (KMO-MSA) > 0.5 dan Loading Factor (Component Matrix) > 0.4.

2. Uji Reliabilitas

Pengujian reliabilitas digunakan untuk mengetahui sejauh mana instrumen penelitian konsisten, artinya alat ukur tersebut mempunyai hasil yang konsisten apabila digunakan berkali-kali pada waktu yang berbeda. Penelitian ini menggunakan teknik Alpha Cronbach ( $\alpha)>0.7$ (Ghozali, 2011).

\subsubsection{Analisis Regresi Linier}

Analisis regresi linier digunakan untuk menguji dan menganalisis apakah ada pengaruh atau tidak antara variabel bebas/ independent terhadap variabel terikat/ dependent. Penelitian ini menggunakan persamaan regresi linier sederhana dengan rumusan :

$\mathrm{Y}=\alpha+\beta \mathrm{X}+\mathrm{e}$

Dimana: $\quad \mathrm{Y}=$ Kinerja dosen.

$\mathrm{X}=$ Kompetensi dosen. 
$\alpha=$ Konstanta pengaruh kompetensi terhadap kinerja dosen.

$\beta=$ Koefisien regresi standar variabel bebas.

e $=$ Standard error, yaitu variabel lain yang tidak masuk dalam model.

\subsubsection{Uji Normalitas Data}

Pengujian bertujuan untuk menguji normalitas distribusi model regresi, variabel pengganggu atau residual. Uji t dan $\mathrm{F}$ mengasumsikan bahwa nilai residual mengikuti distribusi normal. Dalam penelitian ini, digunakan uji statistik non-parametrik Kolmogorov-Smirnov (K-S) dengan sig $>0.05$ yang berarti data berdistribusi normal.

\subsubsection{Uji Asumsi Klasik}

Untuk meyakinkan bahwa persamaan garis regresi yang diperoleh adalah linier dan valid, maka dilakukan pengujian asumsi klasik. Penelitian ini menggunakan uji heteroskedastisitas model Glejser untuk menguji apakah dalam model regresi terjadi ketidaksamaan varians dari residual satu pengamatan ke pengamatan yang lain. Model regresi yang baik adalah yang homoskedastisitas atau tidak terjadi heteroskedastisitas (Ghozali, 2011).

\subsubsection{Uji Model Fit}

1. Uji Signifikansi (Uji Statistik F/ Anova)

Uji statistik F menunjukkan apakah variabel bebas mempunyai pengaruh terhadap variabel terikat (Ghozali, 2011).Untuk mengujinya digunakan statistik F dengan kriteria nilai Fh > Ft atau nilai sig $<0.05$.

\section{Uji $\mathrm{R}^{2}$ (Koefisien Determinasi)}

Pengujian model dilakukan dengan koefisien determinasi (Adjusted $R$ Square) yaitu kemampuan variabel bebas menerangkan variabel terikat. Jika Adjusted $R^{2}$ yang diperoleh dari hasil perhitungan menunjukkan semakin besar (mendekati satu), maka dapat dikatakan bahwa sumbangan dari variabel bebas terhadap variabel terikat semakin besar.

\subsubsection{Uji Hipotesis}

Pengujian hipotesis dalam penelitian ini menggunakan uji t yaitu menguji pengaruh variabel bebas terhadap variabel terikat (taraf signifikansi 5\%). Kriteria uji yang ditetapkan adalah :

1. Sig $\mathrm{t}<0.05$, artinya ada pengaruh yang signifikan antara variabel yang diuji.

2. Sig $\mathrm{t} \geq 0.05$, artinya tidak ada pengaruh yang signifikan antara variabel yang diuji.

Sebagai catatan tambahan, bahwa analisis dalam penelitian ini dilakukan dengan menggunakan bantuan program komputer statistik IBM SPSS (Statistical Package for Social Sciences) Version 20. 


\section{HASIL DAN PEMBAHASAN}

\subsection{Deskripsi Responden}

\subsubsection{Responden Berdasarkan Asal Institusi}

Jumlah responden penelitian ini adalah 54 dosen yang berasal dari 3 pendidikan tinggi maritim di kota Semarang. Secara statistik, asal institusi tersebut adalah 30 orang (56\%) dari Akpelni, 17 orang (31\%) dari Stimart-AMNI, dan 7 orang (13\%) dari ATP Veteran.

\subsubsection{Responden Berdasarkan Jenis Kelamin}

Responden terdiri dari 36 dosen laki-laki dan 18 dosen perempuan.Dengan demikian dapat kita lihat bahwa mayoritas dosen adalah laki-laki sebanyak $66.7 \%$.

\subsubsection{Responden Berdasarkan Usia}

Responden berdasarkan usia dapat digolongkan seperti tampak pada tabel berikut:

\begin{tabular}{|c|c|c|c|c|c|}
\hline & & Frequency & Percent & Valid Percent & Cumulative Percent \\
\hline \multirow{6}{*}{ Valid } & $26-35$ & 15 & 27.8 & 27.8 & 27.8 \\
\hline & $36-45$ & 13 & 24.1 & 24.1 & 51.9 \\
\hline & $46-55$ & 7 & 13.0 & 13.0 & 64.8 \\
\hline & $56-65$ & 12 & 22.2 & 22.2 & 87.0 \\
\hline & $66-75$ & 7 & 13.0 & 13.0 & 100.0 \\
\hline & Total & 54 & 100.0 & 100.0 & \\
\hline
\end{tabular}

\subsubsection{Responden Berdasarkan Tingkat Pendidikan}

Latar belakang dosen berdasarkan ijazah akademik yang dimiliki adalah 2 orang berijazah D3, 18 orang berijazah S1, dan 34 orang berijazah S2. Dari data ini dapat dilihat bahwa ada 37\% dosen yang belum memenuhi standar kualifikasi dosen.

Jika dilihat dari latar belakang pendidikan profesi kepelautan, 33 dosen atau $61.1 \%$ berasal dari latar belakang non-profesi pelaut.Sementara yang berijazah profesi ada 6 orang ANT-I, 4 orang ANT-II, 7 orang ATT-I, dan 4 orang ATT-II.

\subsubsection{Responden Berdasarkan Masa Kerja}

Penggolongan masa kerja responden dapat dilihat pada tabel berikut ini:

\begin{tabular}{|r|r|r|r|r|}
\hline & Frequency & Percent & Valid Percent & Cumulative Percent \\
\hline \multirow{6}{*}{ Valid $1-10$} & 31 & 57.4 & 57.4 & 57.4 \\
$11-20$ & 14 & 25.9 & 25.9 & 83.3 \\
$21-30$ & 4 & 7.4 & 7.4 & 90.7 \\
$31-40$ & 3 & 5.6 & 5.6 & 96.3 \\
$41-50$ & 2 & 3.7 & 3.7 & 100.0 \\
Total & 54 & 100.0 & 100.0 & \\
\hline
\end{tabular}




\subsection{Hasil Pengujian Kualitas Instrumen}

\subsubsection{Uji Validitas}

1. Validitas Instrumen Pengukur Kinerja (Y)

Pada saat dilakukan pengujian validitas pertama kali, didapatkan nilai KMO-MSA 0.735 dan ada 3 indikator yang tidak valid karena Componen Matrix-nya < 0.4 yaitu KI1 (0.352), KI2 (0.395), dan KI5 (0.376). Oleh karena itu dilakukan pengujian ulang dengan membuang ketiga indikator, sehingga terdapat 16 butir kuesioner dan hasil pengukuran validitasnya diperoleh sebagai berikut :

\begin{tabular}{|ll|r|}
\hline Kaiser-Meyer-Olkin Measure of Sampling Adequacy. & .774 \\
Bartlett's Test & Approx. Chi-Square & 357.678 \\
of Sphericity & df & 120 \\
& Sig. & .000 \\
\hline
\end{tabular}

2. Validitas Instrumen Pengukur Kompetensi (X)

Pada saat dilakukan pengujian validitas pertama kali, didapatkan nilai KMO-MSA 0.540 dan ada 2 indikator yang tidak valid yaitu KOM9 (0.365) dan KOM44 (0.279). Oleh karena itu dilakukan pengujian ulang dengan membuang kedua indikator, sehingga terdapat 42 butir kuesioner dan hasil pengukuran validitasnya diperoleh sebagai berikut :

\begin{tabular}{|ll|r|}
\hline Kaiser-Meyer-Olkin Measure of Sampling Adequacy. & .660 \\
Bartlett's Test & Approx. Chi-Square & 1782.954 \\
of Sphericity & df & 861 \\
& Sig. & .000 \\
\hline
\end{tabular}

\subsubsection{Uji Reliabilitas}

Pada pengujian reliabilitas bersama untuk kedua variabel, diperoleh nilai Alpha Cronbach $(\alpha)=0.961$. Jika dipecah tiap variabel, maka untuk kinerja diperoleh nilai 0.872 dan untuk kompetensi diperoleh nilai 0.959. Hal ini sudah melebihi kriteria 0.7, oleh karena itu pengujian dengan menggunakan instrumen tersebut dapat dilanjutkan.

\subsection{Hasil Analisis Regresi Linier}

Sebelum dilakukan analisis regresi linier, perlu diketahui hasil analisis statistika terhadap masing-masing variabel.Analisis terhadap variabel kinerja menunjukkan nilai minimal 2.88 dan rata-rata 3.9722, sedangkan variabel kompetensi memiliki nilai minimal 3.52 dan rata-rata 4.2478. Dari analisis ini, dapat dikatakan bahwa kompetensi dosen sudah cukup tinggi namun kinerjanya masih harus ditingkatkan. 
Selanjutnya, dilakukan analisis koefisien regresi dengan hasil sebagai berikut:

\begin{tabular}{|c|c|c|c|c|c|}
\hline \multirow[t]{2}{*}{ Model } & \multicolumn{2}{|c|}{ Unstandardized Coefficients } & Standardized Coefficients & \multirow[t]{2}{*}{$\mathrm{t}$} & \multirow[t]{2}{*}{ Sig. } \\
\hline & B & Std. Error & Beta & & \\
\hline (Constant) & .930 & .497 & & 1.872 & .067 \\
\hline MEAN_KOM & .716 & .116 & 649 & 6.149 & .000 \\
\hline
\end{tabular}

Jika kita melihat hasil perhitungan pada tabel di atas, maka dapat dituliskan rumusan persamaan regresi linier: $\mathrm{Y}=0.930+0.716 \mathrm{X}$

Dimana :

$\mathrm{Y} \quad=$ Kinerja dosen

$\mathrm{X}=$ Kompetensi dosen

$0.930=$ Konstanta pengaruh kompetensi terhadap kinerja dosen

$0.716=$ Koefisien regresi standar

Hal ini berarti setiap kenaikan 1 kali pada kompetensi dosen, akan meningkatkan kinerja dosen sebesar 0.716 .

\subsection{Hasil Pengujian Normalitas Data}

Pengujian normalitas data menghasilkan nilai sebagaimana tampak pada tabel berikut:

\begin{tabular}{|ll|r|}
\hline & & Unstandardized Residual \\
\hline $\mathrm{N}$ & & 54 \\
Normal Parameters & & \\
& Std. & .31352583 \\
& Deviation & .131 \\
Most Extreme Differences & Absolute & .131 \\
& Positive & -.096 \\
Kolmogorov-Smirnov Z & Negative & .965 \\
Asymp. Sig. (2-tailed) & & .310 \\
\hline
\end{tabular}

a. Test distribution is Normal.

b. Calculated from data.

Berdasarkan tabel di atas, kita lihat nilai sig 0.310.ini di atas kriteria sig $>0.05$, dan dengan demikian berarti dapat dinyatakan bahwa data berdistribusi normal.

\subsection{Hasil Pengujian Asumsi Klasik}

Setelah dilakukan regresi variabel independen terhadap residual mutlak sebagai variabel dependen, didapat nilai sig 0.505. Hal ini melebihi kriteria $<0.05$ yang berarti tidak ada signifikansi dan berarti pula tidak terjadi heteroskedastisitas pada model ini, sehingga penelitian ini memenuhi persyaratan asumsi klasik. 


\subsection{Hasil Pengujian Model Fit}

\subsubsection{Uji Signifikansi (Uji Statistik F/ Anova)}

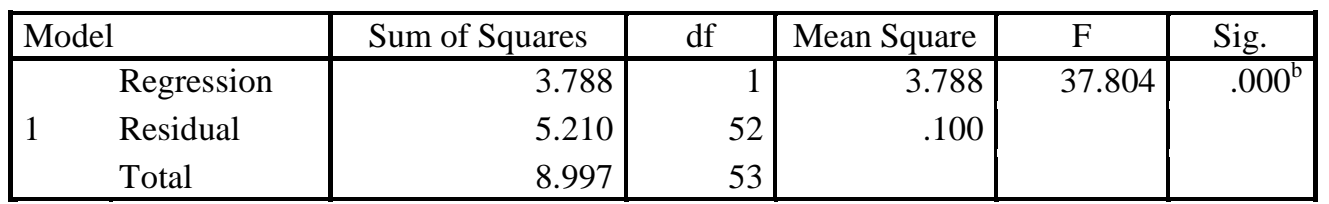

a. Dependent Variable: MEAN_KI

b. Predictors: (Constant), MEAN_KOM

Jika diperhatikan kolom sig pada tabel di halaman sebelumnya, dapat diketahui bahwa nilainya adalah 0.000 (< 0.05). Hal ini menandakan bahwa variabel $\mathrm{X}$ (kompetensi dosen) berpengaruh signifikan terhadap Y (kinerja dosen).

\subsubsection{Uji $\mathbf{R}^{2}$ (Koefisien Determinasi)}

\begin{tabular}{|c|c|c|c|c|c|c|c|c|c|}
\hline \multirow[t]{2}{*}{ Model } & \multirow[t]{2}{*}{$\overline{\mathrm{R}}$} & \multirow{2}{*}{$\begin{array}{c}\mathrm{R} \\
\text { Square }\end{array}$} & \multirow{2}{*}{$\begin{array}{l}\text { Adjusted } \\
\text { R Square }\end{array}$} & \multirow{2}{*}{$\begin{array}{l}\text { Std. Error } \\
\text { of the } \\
\text { Estimate }\end{array}$} & \multicolumn{5}{|c|}{ Change Statistics } \\
\hline & & & & & $\begin{array}{c}\text { R Square } \\
\text { Change }\end{array}$ & $\begin{array}{c}\mathrm{F} \\
\text { Change }\end{array}$ & df1 & $\mathrm{df} 2$ & $\begin{array}{c}\text { Sig. F } \\
\text { Change }\end{array}$ \\
\hline 1 & $.649^{\mathrm{a}}$ & .421 & .410 & .31653 & .421 & 37.804 & 1 & 52 & .000 \\
\hline
\end{tabular}

a. Predictors: (Constant), MEAN_KOM

b. Dependent Variable: MEAN_KI

Adjusted $R^{2}$ yang diperoleh dari hasil perhitungan menunjukkan nilai 0.410, maka dapat dikatakan bahwa sumbangan dari kompetensi dosen terhadap kinerjanya adalah sebesar 41\%, sedangkan sisanya sebesar 59\% adalah faktor lain yang turut mempengaruhi kinerja dosen namun tidak diteliti dalam penelitian ini

\subsection{Hasil Pengujian Hipotesis}

Untuk memastikan kebenaran rumusan hipotesis dari Bab-I, dapat dilihat kembali tabel pada hasil pengujian regresi linier (poin 3.3). Nilai $\operatorname{sig} \mathrm{t}=0.000$, ini sesuai dengan kriteria $\operatorname{sig} \mathrm{t}<$ 0.05. Sehingga dapat dikatakan bahwa hipotesis diterima, yaitu ada pengaruh yang signifikan dari kompetensi dosen terhadap kinerjanya.

Hasil penelitian ini sejalan dengan penelitian terdahulu oleh Soo-Young Shin dan Won-Woo Park (2009), Fajar Apriani (2009), Sosiawan Ma'mun (2013), Ruslan Ade Kamis, Noermijati, dan Christin Susilowati (2013), Rusminingsih dan Euis Soliha (2014), serta Alamsyah Lotunani, M.S. Idrus, Eka Afnan, dan Margono Setiawan (2014). Namun bertentangan dengan hasil penelitian dari Prihatin Triyanto (2010), serta Endang Setyaningdyah, Umar Nimran, Kertahadi, dan Armanu Thoyib (2013). 


\section{KESIMPULAN DAN SARAN}

\subsection{Kesimpulan}

Berdasarkan pembahasan pada Bab-III, dapat ditarik kesimpulan sebagai berikut:

1. Nilai rata-rata kompetensi dosen sebesar 4.25 menunjukkan bahwa dosen perguruan tinggi maritim swasta di kota Semarang sudah cukup tinggi. Sementara itu di sisi lain, nilai tingkat kinerja dosen sedikit lebih rendah yaitu sebesar 3.97 .

2. Rumusan regresi linier $\mathrm{Y}=0.93+0.72 \mathrm{X}$ menunjukkan bahwa setiap kenaikan 1 kali pada kompetensi dosen, akan meningkatkan kinerja dosen sebesar 0.72.

3. Hipotesis awal dinyatakan dapat diterima karena kompetensi dosen terbukti memiliki pengaruh positif dan signifikan terhadap kinerja dosen. Kompetensi menyumbang $41 \%$ terhadap kinerja, sementara sisanya merupakan pengaruh dari faktor-faktor lain yang tidak masuk dalam model penelitian ini.

\subsection{Saran}

Terkait dengan kesimpulan di atas dan adanya keterbatasan pada penelitian ini, maka penulis mengajukan beberapa saran berikut ini:

1. Kinerja dosen perguruan tinggi maritim swasta di kota Semarang harus terus ditingkatkan. Salah satu hal yang bisa dilakukan adalah dengan meningkatkan kompetensinya karena dari hasil penelitian ini menunjukkan bahwa kompetensi dosen dapat mempengaruhi kinerjanya. Contoh praktis peningkatan kompetensi adalah dengan memberikan dukungan agar dosen yang masih berijazah D3 dan S1 untuk menempuh studi lanjut ke jenjang S2.

2. Penelitian ini hanya dilakukan di 3 perguruan tinggi maritim swasta di kota Semarang dan menggunakan studi persepsi diri, oleh karena itu perlu kehati-hatian dalam melakukan generalisasi. Untuk pengembangan pendidikan maritim, penelitian dapat dikembangkan untuk wilayah yang lebih luas dan juga dilakukan di perguruan tinggi maritim negeri atau yang diselenggarakan oleh pemerintah.

3. Penelitian lebih lanjut juga perlu dilakukan untuk mengetahui faktor-faktor lain yang turut mempengaruhi kinerja dosen, dimana hasil penelitian ini menunjukkan sebesar 59\%. Dari pengamatan penulis, beberapa faktor yang patut diduga antara lain adalah kompensasi, komitmen organisasional, dan gaya kepemimpinan. 


\section{DAFTAR PUSTAKA}

Anggraeni, Rinny D. (2013). Increasing Lecturer Competence as the Quality Assurance of Lecturer Performance.Proceedings of $7^{\text {th }}$ Global Business and Social Science Research Conference, 13 (June), $1-28$, Beijing.

Apriani, Fajar (2009). Pengaruh Kompetensi, Motivasi, dan Kepemimpinan terhadap Efektifivitas Kerja. Jurnal Ilmu Administrasi dan Organisasi, 16 (1), 13 - 17.

Azwar, Saifuddin (2010). Metode Penelitian, Edisi 1. Yogyakarta, Pustaka Pelajar Offset.

Boulter, N., Dalziel, M., \& Hill J., (2003). People and Competencies: The Route to Competitive Advantage, alih bahasa Bern Hidayat. Jakarta, PT. Gramedia Pustaka Utama

Ghozali, Imam (2011). Aplikasi Analisis Multivariate dengan Program IBM SPSS 19, Edisi 5. Semarang, BP Universitas Diponegoro.

Indrawijaya, Adam I. (2010). Teori, Perilaku, dan Budaya Organisasi, Edisi 1. Bandung, PT. Refika Aditama

Kamis, R.A., Noermijati, \& Susilowati, C. (2013). The Influence of Organizational Commitment and Individual Competence on Teacher Performance: In The Learning Organization Perspective. International Journal of Business and Behavioral Sciemces, 3 (8), 19 - 35.

Keban, Yeremias T. (2008). Enam Dimensi Strategis Administrasi Publik-Konsep, Teori dan Isu, Edisi 2. Yogyakarta, Gava Media

Kementerian Pendidikan dan Kebudayaan.(2014). Pedoman Sertifikasi Pendidik untuk Dosen (Serdos) Terintegrasi, Buku 1 Naskah Akademik. Jakarta, Direktorat Jenderal Pendidikan Tinggi.

Lotunani, A., Idrus, M.S., Afnan, E., \& Setiawan, M. (2014).The Effect of Competence on Commitment, Performance and Satisfaction with Reward as a Moderating Variable.International Journal of Business and Management Invention, 3 (2), 18 - 25.

Ma'mun, Sosiawan (2013). The Effect of Competence, Motivation, and Work Moral to the Organizational Commitment ata Sulawesi Regional Kopertis IX of Indonesia.Journal of Basic and Applied Scientific Research, 3 (12), 403 - 409.

Peraturan Pemerintah Republik Indonesia Nomor 37 Tahun 2009 tentang Dosen.

Rusminingsih \& Soliha, E. (2014). Pengaruh Kompetensi Guru dan Karakteristik Pekerjaan terhadap Kinerja dengan Mediasi Komitmen Organisasional. Jurnal Bisnis dan Manajemen, 2 (1), $73-88$. 
Setyaningdyah, E., Nimran, K.U., \& Thoyib, A. (2013). The Effect of Human Resource Competence, Organisational Commitment and Transactional Leadership on Work Discipline, Job Satisfaction and Employee's Performance.Interdisciplinary Journal of Contemporary Research in Business, 5 (4), 140 - 153.

Soo-Young Shin \& Woon-Woo Park (2009). Moderating Effects of Group Cohesiveness in Competency-Performance Relationship: A Multi-Level Study.Journal of Behavioral Studies in Business, 1 (July), 1 - 15.

Spanbauer, Stanley J. (1992). A Quality System for Education. Milwaukee-Wisconsin, ASQC Quality Press

Sudarmanto (2014). Kinerja dan Pengembangan Kompetensi SDM - Teori, Dimensi Pengukuran, dan Implementasi dalam Organisasi, Edisi 2. Yogyakarta, Pustaka Pelajar.

Sugiyono (2010). Metode Penelitian Administrasi. Bandung : CV. Alfabeta.

Triyanto, Prihatin (2010). Kompetensi Dosen Hubungannya dengan Praktek Organisasi Perguruan Tinggi Swasta di Kopertis Wilayah VI Jawa Tengah.Akses: Jurnal Ekonomi dan Bisnis, 5 (9), $36-52$.

Undang-Undang Republik Indonesia Nomor 14 Tahun 2005 tentang Guru dan Dosen.

Undang-Undang Republik Indonesia Nomor 12 Tahun 2012 tentang Pendidikan Tinggi.

Uno, H.B. \& Lamatenggo, N. (2014). Teori Kinerja dan Pengukurannya, Edisi 1. Jakarta, PT. Bumi Aksara.

Usman, Husaini (2006). Manajemen Teori, Praktek dan Riset Pendidikan. Jakarta, Bumi Aksara.

Whitmore, John (1997). Coaching for Performance; Seni Mengarahkan untuk Mendongkrak Kinerja, alih bahasa Dwi Helly Purnomo dan Louis Novianto. Jakarta, Gramedia Pustaka Utama.

Wibowo (2011). Manajemen Kinerja, Edisi 3. Jakarta, Rajawali Pers

William, Richard (2002). Managing Employee Performance. London, Thomson Learning Zwell, Michael (2000). Creating A Culture of Competence. New York, John Wiley \& Sons 